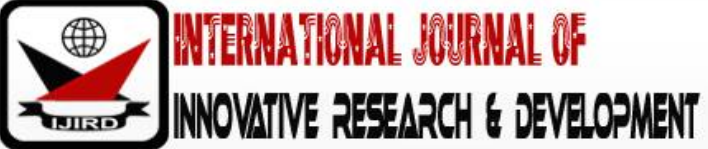

ISSN 2278 - 0211 (Online)

\section{Participation of Females in Communication for Development by Migori County Government, Kenya}

Otieno Millicent Awuor
PhD. Student, Department of Communication Journalism and Media Studies,
Rongo University, Kenya
Agalo Jerry
Associate Professor, Department of Communication Journalism and Media Studies,
Rongo University, Kenya
Peter Day
Senior Lecturer, Department of Communication and Media Studies,
University of Brighton, England

\begin{abstract}
:
Participation is key to the success of communication for development. Failure to institute the participation of key change agents in development result to ineffective outcome of development projects. The purpose of this study was to establish participation of females in communication for development by Migori County government. The study was guided by Gidden's structuration theory. Exploratory research was employed as a research design for the study. Data was collected through interview responses from the county director of gender, 2 ward administrators, 15 leaders of 10 women groups, 10 members of 10 women groups found in Nyatike and Kuria East Sub counties. Focus group discussion involving 8 women and 7women in Nyatike and Kuria East respectively was also conducted. The total number of participants for the study was 43. Data was also collected through document analysis of the genderpolicy, Migori County Integrated Development Plan and communication for development messages from radio Milambo. The county director of gender and the leaders of women groups were purposively sampled to take part in the study, the other women - members of the registered groups were chosen through snow ball sampling, the ward administrators were chosen through simple random sampling. The reliability of the instrument was tested through Cohen Kappa Method to test reliability of themes from the inter-rater. Data was analysed through thematic analysis. Data was presented in form of themes and pie-charts.The study found out that females in Migori County rarely participate in communication for development and the few times they do participate, it is at the level of information sharing. The study recommends that gender mainstreaming should be considered as an important component of communication for development for Migori County government to realise its development objectives for the females. Exclusive meetings for females should be instituted so as to enable effective participation of females. In addition, the county government should have a database of all the women groups in the county to facilitate communication with the groups.
\end{abstract}

Keywords: Communication for development, participation, development

\section{Introduction}

\subsection{Communication for Development}

Communication is considered a critical element of development (Akpan,2012). Communication for development refers to the uses for which communication is applied to advance development (Rogers, 2016). Communication for development is about such communication that can be used for development. It is about using communication to bring change or improve the way of living of the citizen of a country. The messages which are designed to transform the behavior of people or for improving their quality of life can be termed as communication for development and these messages are used to change the socio-economic condition of people. Though communication for development grew out of agricultural communication, the term comprehensively includes not only agriculture but also population, nutrition, health, education, housing, employment and so on. Because all these areas require communication inputs to expedite the process of development, development communication has vast scope for its reach and utility in development (Khalid, 2012).

Communication for development is not merely a matter of transmitting information about how things can be done better by using available facilities. It is much more than the exchange of problem-solving information. It also involves the generation of psychic mobility or empathy, raising of aspirations, teaching of new skills and encouragement of local participation in development activities. Communication for development assumes the broader function of helping people to restructure their mental framework in interpreting specific events and phenomena, and to relate to the broader world 
beyond their immediate environments. To be effective in doing this, communication activities in development must be inter-woven with other socioeconomic and political processes (Moemena ,2010).

\subsection{Participation}

Communication is essential to human, social, and economic development. At the heart of Communication for development is participation and ownership by communities and individuals most affected by poverty and other development issues, (The Rome Consensus, 2002),

The term participation is generally operationalized differently depending on the context and field in which it is studied which makes it uneasy to be conceptualized (Samad, 2002). No consensus exists around a common definition of participation: it varies depending on the perspective applied. Some stakeholders define participation as the mobilization of people to eliminate unjust hierarchies of knowledge, power, and economic distribution. Others define it as the reach and inclusion of inputs by relevant groups in the design and implementation of a development project. These examples represent two of the main approaches to participation: a social movement perspective and a project-based or institutional perspective. These perspectives share a common understanding of participation as the involvement of ordinary people in a development process leading to change. Their scope and methods, however, can differ, World Bank ( 2009).Up off et al 1979 in Fekade, (1994), for instance, realized that political scientists tend to conceptualize participation in terms of involvement of rural people in decision making, economists often in terms of rural people sharing in benefits, development administrators concentrate on rural people assuming roles in implementation when they make reference to participation.

In ancient Greece, participation was viewed as a matter of voting, holding offices, attending public meetings, paying taxes and defending the state (ibid). But in modern times participation became synonymous with sharing (Kaler, 1999). Oakley \& Marsden (1984) and Wolfe (1994) put forward that participation is closely linked with the concept of empowerment. Without empowerment participation may be meaningless. People's participation is the process of empowerment of the deprived, marginalized and the excluded (Samad, 2002).Cohen \& Uphoff (1980) view participation with regard to development projects as "people's involvement in decision making processes, in implementing program, their sharing in the benefits of development programs and their involvement in efforts to evaluate such programme. Mohammad (2010) defines participation as the active involvement of the local people in the planning and implementation of development projects and argues that for effective plan formulation, control of projects and sharing of benefits of development to actualise, participation is necessary.

The World Bank (1992) defines participation as a process through which stakeholder's influence and share control over their own development initiatives, decisions and resources which affect them. It is evident from this definition that the World Bank has clubbed together all stakeholders, ignoring inequalities which affect the different stakeholders, particularly those who are poor and marginalized, to take part effectively in decision making (Tandon and Cordeiro, 1998). The USAID (1995), on the other hand, defines participation as: "an active engagement of partners and customers in sharing ideas, committing time and resources, making decisions and taking action to bring about a desired development objective". Adding gender dimensions to the development process, the Department for International Development in United Kingdom defines participation as: "a participatory approach that takes into account the views and needs of the poor and tackles disparities between men and women throughout society" (Feeney, 2006).

The German Agency for Technical Co-operation (GTZ) promoting self-determination considers participation as: "a principle to promote initiative, self-determination and the taking over of responsibility by beneficiaries, thus representing a critical factor for meeting project's objectives" (Foster, 1986). With this meaning, participation aims at an increase in self-determination and readjustment of control over development initiatives and resources (Boakye-Agyei, 2009).

According to the Swedish Development Co-operation Agency (SIDA), participation is a basic democratic right that should be promoted in all development projects considering the means of increasing efficiency, effectiveness and sustainability in development project (Rudqvist \& Woodford-Berger, 1996). In this definition, SIDA laid emphasis on equity and democracy. Khan (1993) simplifies the definitions of participation as follows;

- An organized effort to increase control over resources and regulative institutions;

- People's involvement in decision-making, implementation, benefit-sharing and in evaluation of programmes;

- People's capacity to take initiative in development, to become "subjects" rather than "objects" of their own destiny; this can only be achieved through a professionalization in all domains of life in order to make "ordinary people" responsible for their own well-being;

- Participation involves a reversal of role playing: people should be the primary actors and government agencies and outsiders should "participate" in people's activities.

Citizen participation is a categorical term for citizen power. It is the redistribution of power that enables the havenot citizens, presently excluded from the political and economic processes, to be deliberately included in the future. It is the strategy by which the have-nots join in determining how information is shared, goals and policies are set, tax resources are allocated, programs are operated, and benefits like contracts and patronage are parcelled out. In short, it is the means by which they can induce significant social reform which enables them to share in the benefits of the affluent society (Arnstein, 1969).

\subsection{Development}

Development entails the process of economic and social transformation that is based on complex sets of economic, social, cultural, socio-cultural and environmental factors and their interactions that may result in improvement of the overall human wellbeing (Ngomba, 2016; Thomas, 2017). Development is viewed as a widely participatory process of social change in a society, intended to bring about both social and material advancement, including greater equality, 
freedom, and other valued qualities for the majority of people through their gaining greater control over their environment (Servaes, 2008; Bourgignon, 2015). Historically it has largely been synonymous with economic development, but has recently been used in a holistic and multi-disciplinary context of human development as well as other concepts like quality of life or subjective well-being (Thomas, 2017).

This study adopted the definition of development as access to information and effective communication which enhances the socio-economic status of a people. This definition leans on the definition of development by Sen, (1999) that regards timely access to information as an enabler of development. This definition is critical to the study since the study is based on the premise that development status of females in the selected areas of Migori County has not improved due to challenges in accessing pertinent information on development opportunities within the county as a result of the manner in which communication for development is conducted.

\subsection{The Developmental Role of the County Government}

The Constitution of Kenya (2010) specifies the national values and principles of governance which consist of distribution and decentralisation of power. In view of this, a two-tier government was created: a national government and 47 county governments. The Fourth Schedule delineates the functions of the different tiers of government. The constitution of Kenya mandates each county to prepare a four year development plan referred to as the County Integrated Development Plan. The county integrated development plan is an instrument for examination of the people's priorities, capacities, and potential partnerships, identification of inequities and measurement of development at the country level.

Migori County Integrated Development Plan (2013-2017) conforms with and is informed by the National aspirations, the county vision and mission and the strategic direction provided by Kenya Vision 2030.The Vision is anchored on three pillars namely: the Economic, Social and Political Pillars. The Economic Pillar aims at achieving and maintaining a stable economic growth rate of 10 per cent or more annually up to 2030.The social pillar's goal is to create a just and cohesive society enjoying equitable social development in a clean and secure environment. The political pillar aims to create an issue-based, people-centred, result-oriented, and accountable democratic political environment.

According to Migori County Integrated Development Plan, (2013-2017), Migori county development agenda is premised on four pillars; Socio-economic empowerment, infrastructural development, affirmative action and environmental management.Socio-economic development focusses on the provision of enhanced security, improved food sufficiency, excellent and affordable health care and shelter services, enhanced opportunities for industrial development, self-reliant jua-kali and job creation, improved education standards and skills development at all levels, enhanced sports and talent development as well as improved tourism activities. Various human development indices would be applied to measure the broad level of social economic wellbeing.

Infrastructural development as enshrined in the Migori County Integrated development plan include measures to improved road networks within the county by constructing certain roads to bitumen standards so as to necessitate efficient marketing and tourism among others. Infrastructural development also aimed to improve water and air transport. In addition, it entails the provision of potable and accessible sources of water.

Affirmative action is the third form of development plan as outlined in the Migori County Integrated development plan 2013-2017. Affirmative action aims to improve youth empowerment, enhance care for the elderly, orphans and less privileged members of the society, improved care for the women and people living with HIV and AIDS. The Constitution of Kenya, 2010 in Article 27 recognizes that measures should be put in place to encourage affirmative action programmes and policies to address past inequalities. Economic and social rights to all are also recognized in Article 43. These include the right to health care services, adequate housing, and sanitation, adequate food of acceptable quality, clean and safe water and appropriate social security to vulnerable groups in the society.

According to MCDP, (2013), the following are the plans towards the advancement of the social and economic livelihoods of women: providing loans and grants to women groups, support in the agricultural sector through the provision of seed capital as well as training and capacity building. This study interrogates the plans with a bias to communication for development targeting females and its role in enhancing the development status of females. The study is premised on the belief that access to information and effective participation in communication for development are key to the realization of affirmative action plan as outlined in the Migori County Integrated Development Plan.

\subsection{Statement of the Problem}

Low uptake of development in many parts of Kenya has been acknowledged for several decades (Rees,et al, 2016). Efforts are aimed at ensuring that resources are developed into the grassroot to enhance development agenda. As a result several counties are currently undertaking many projects aimed at alleviating poverty among the people at the local levels through the devolution programme (Clarity, 2013 ). One of the aims of devolution was to improve the livelihoods of the people , among whom ,women make up a critical mass. Migori county government has initiated a number of development projects with the aim of uplifting the livelihood of women however, the women remain poor. Migori County ranks 25 out of 47 counties in the poverty index ranking in Kenya (Economic Survey, 2017).The development indices of literacy of women, fertility and child mortality in Migori County is ranked number 30, 35, 40 respectively out of the 47 counties in Kenya (Kenya Housing and Population Survey, 2016). The development projects fail to realize the intended objective because the county government does not involve females in the process of communication for development.According to Mafalopolus (2012) development tends to fail for two basic reasons: lack of participation and ineffective communication. 


\subsection{Study Area}

The research was carried out in Migori County, Kenya. Migori County is a county in the former Nyanza Province of South Western part of Kenya. The study area- Migori County is situated in western Kenya. The neighboring countries of Migori County are: Homa Bay County situated to the north, Kisii to the north east, Narok to the east and south east, Tanzania to the south and south West and Lake Victoria to the west of Migori County. The capital of the county is Migori town, which is also its largest town. According to the 2009 population census, the total population of Migori County was 917,170 comprising of 444,357 males $(48.6 \%$ ) and 472,814 females $(51.4 \%)$ (KNBS ,2010). The projected population growth of Migori County is of 3.8 per cent per annum resulting to 1,028,028 persons in the year 2012, $1,152,165$ persons in 2015 and 1,243,272 persons in the year 2017 ( KNBS, 2010).

The population density is 353 persons $/ \mathrm{km}^{2}$. An estimated 85 percent of the entire land area in the region is arable and can be classified as high potential but the poverty level in the area stands at $43 \%$ as per (KHPS, 2017). Migori county comprises of 8 sub-counties, 23 divisions, 88 locations and 202 sub- locations (County Commissioner's Office, Migori 2013)

\section{Literature Review}

\subsection{Participatory Development Communication}

According to The Rome Consensus (2002) the ideal communication for development should be participatory. Rome Consensus underscores the participatory nature of development communication, it states that development organizations must assign a much higher priority to the essential elements of Communication for Development process, as shown by research and practice.

Bessette (2004), defines participatory development communication as a planned activity, based on the one hand on participatory processes, and on the other hand on media and interpersonal communication, which facilitates a dialogue among different stakeholders, around a common development problem or goal, with the objective of developing and implementing a set of activities to contribute to its solution, or its realization, and which supports and accompanies this initiative. Servaes (2003) elaborates participatory communication for development as where the point of departure must be the community: It is at the community level that the problems of living conditions are discussed, and interactions with other communities are elicited. The most developed form of participation is self-management. This principle implies the right to participation in the planning and production of media content.

It should be noted that not everyone wants to or must be involved in its practical implementation .More important is that participation is made possible in the decision-making regarding the subjects treated in the messages and regarding the selection procedures. Beyond the micro or community/local level, participatory communication in development also applies at the international, national, as well as project management (organizational) and individual level. Its foundation is in (Freire's, 1970) basic model of the dialogue, originally asserted in the context of educating the underdeveloped sectors of society, now considered an important development communication model.

Tapping into local knowledge is viewed as a necessary course of action if a development project is to be successful. It is what makes participatory communication projects unique (Howley, 2010). Participatory development communication assumes that individuals should be active in development programmes and processes; they could contribute ideas, take the initiative and articulate their needs and problems while, at the same time, asserting their autonomy (Baofo, 2006). Therefore, emphasis is on the process of planning and the utilization of communication resources, channels, approaches and strategies in programmes which are designed to bring about some progress, change or development, as well as the involvement of the developing community in the change efforts.

With the abovementioned shift in focus from the linear mode of communication during the modernization era to full participation of the developing community, there is no longer an attempt to disseminate information to communities, but rather to involve the communities fully in both identifying their needs and taking ownership of activities and information. Cohen (1996) states that community participation is a process and it is also a measure of how much is being done by the developing community for themselves with a view to taking control of their own lives and the environment in a self-reliant effort. Participation is thus also a vital criterion for development communication (Tri 1986 \& Rahim1994).

The point of departure for development communication is, according to Bessette (2003), not the dissemination of an innovation, or of a new idea that is full of promise, but the grassroots expression of the community's needs. This relates to the concept of participation which plays a vital role in normative contemporary views on development.

Participatory development communication - the process by which people become leading actors in their own development - enables people to become generators of their own development as opposed to being mere recipients of external development interventions. At the heart of the concept of development communication is the need for an exchange of information in order both to contribute to the resolution of a development problem and to improve the quality of life of a specific community (Bessette, 2003). Despite the fact that participation is sometimes viewed as being synonymous with development, it has not always been practiced in this manner.

Thomas (1994) adds that participation has brought back to discourse the emphasis on a praxis that has emerged from the developing community as a mirror of their aspirations and needs, rather than as one which has been imposed on them by others. This has allowed people to become the subjects of their own development and not simply the objects of either technology or processes on a praxis that has emerged from the developing community as a mirror of their aspirations and needs, rather than as one which has been imposed on them by others. This has allowed people to become the subjects of their own development and not simply the objects of either technology or processes. 
Paulo Freire, an educational theorist, incorporates participation as a key concept in his philosophy and he indicates that participation is based on the notion that the historical vocation of human beings is to be free from anything in life that does not provide for the involvement of people in the processes of change. Freire's theory focuses on the premise that, in order for communication to be effective, it is essential that it be participatory, dialogic and reciprocal (Freire, 1970).

According to Thomas (1994), Freire's concept of 'dialogue emanated from Martin Buber, an Austrian born Jewish philosopher who is well known for his philosophy of dialogue. His philosophy deals with two types of relationships - the "l-Thou" and the "1-It". The "l-Thou" encounter is one of dialogue, mutual respect, openness and give and take, and it is the basis for communion which is the key to community. In contrast, the "l-lt" relationship is one of monologue, inequality, objectivity and the detachment of human beings from one another, from nature and from God. Buber states that it is in the actual reaching out to the other and in the affirmation of the otherness of the other, that genuine dialogue takes place.

This study is based on Freirean dialogue which incorporates the concept of conscientization which, in turn, focuses on bringing the individual to critical reflection about his/ her own living conditions in terms of which he/ she actively participates in this reflection process (Servaes, 1996). Accordingly, communication for social change involves people taking the communication processes that will allow them to make their voices heard into their own hands to establish horizontal dialogue with planners and development specialists, and to make decisions on those development issues that affect their lives in order, ultimately, to achieve social changes for the benefit of their community (GCIS, 2009; Baofo, 2006).

According to Naidoo (2006) it should be noted that it is necessary to reassess power relationships if development communication initiative is to be successful. A dynamic interpretation of power suggests that, even the powerless are able to acquire a measure of power over their own lives, this will result in a degree of power over other power-holders. A logical deduction would then be that power for the powerless may emerge from their becoming more self-reliant and developing a voice of their own (Nair \& White, 1994).

\subsection{The Place of Participation in the County Government}

The Constitution of Kenya (2010) as well as the County Government Act (2012) gives provision and means for participation of its citizens. According to section 87 of the County Government Act (2012), citizen participation in County governments shall be based upon the following principles:

- Timely access to information, data, documents, and other information relevant or related to policy formulation and implementation;

- Reasonable access to the process of formulating and implementing policies, laws, and regulations, including the approval of development proposals, projects and budgets, the granting of permits and the establishment of specific performance standards;

- Protection and promotion of the interest and rights of minorities, marginalised groups and communities and their access to relevant information;

- Legal standing to interested or affected persons, organisations, and where pertinent, communities to appeal from or, review decisions, or redress grievances, with particular emphasis on persons and traditionally marginalised communities, including women, the youth, and disadvantaged communities;

- Reasonable balance in the roles and obligations of county governments and non-state actors in decision making processes to promote shared responsibility and partnership, and to provide complementary authority and oversight;

- Promotion of public-private partnerships, such as joint committees, technical teams, and citizen commissions, to encourage direct dialogue and concerted action on sustainable development

- Recognition and promotion of the reciprocal roles of non-state actors' participation and governmental facilitation and oversight.

There are several other areas of interest of note where citizens have been given an avenue to participate in the governance of their country. Section 15 of the County Government Act,(2012) grants any person power to petition the county assembly to consider any matter within its authority, including enacting, amending or repealing any of its legislation (Devolution Handbook, 2014).

Public participation in the county planning process is mandatory as indicated in section 113 of the County Government Act, 2012. It even goes on further to list the various avenues that the county should make available for the people to participate. These include: information communication technology based platforms, town hall meetings, budget preparation and validation as well as notice boards for dissemination of important information of public interest.

\subsection{Gender and Participation}

Whereas feminists and advocates of women's rights, mainly women, have attempted to support gender equality in development, a different set of scholars and practitioners, primarily from backgrounds in rural development policy and practice, have put concerted efforts to promote participatory development. Although there have existed similarities in the methods used (Moser, 1993), gender advocates have from time to time overlooked the significance of participation. On the same note, assessment of pioneer works promoting participatory methods underlined shortcomings in terms of the focus on gender. In the recent past, significant discussions have been held to chart way forward on how to combine approaches and promote both gender equality and participation in policy and planning processes, as well as in development programmes and projects (Guijt \&Shah, 1998; Cornwall, 2000).

The general objective of participatory development is to intensify the involvement of socially, economically and often politically disadvantaged people in the decision-making about their own lives. Nevertheless, there have been 
concerns as to whether participatory development initiatives have actually addressed differences and inequalities based on age, wealth, religion, caste, race, ethnicity and gender. Dating back to, 1996, an article in PLA Notes 16 documented wellbeing ranking exercises with different sets of groups in a village in Sierra Leone (Welbourn, 1996). The outcome of the exercises demonstrated how talking to better-off men, as was usually the norm of most development project staff, was totally insufficient as a means of assessing the complexity of the needs of community. Another case in point is the study of community forestry management in India by Sarin, (1998), in which he demonstrated how wealthy village men are apt to dictate the community priorities and decisions, while the women whose livelihoods are intertwined much more with the forests are compelled to abide by the men's. More often than not, the belief that of communities as cohesive and harmonious still underpin participatory development initiatives: a factor that sometimes undermine participatory development initiatives since communities are fragmented by age, class, caste and gender among others. Lennie \&Tacchi(2013) further argue that while the participation of women is a fundamental principle for development, it is often difficult to carry through because of gender inequalities in many societies.

Even when the different interests in communities are acknowledged, there is a propensity to underrate the complexities of conflict and negotiation at this level. Ideally, participatory development consist of the equal inclusion of all sections of a typical, stratified community: women, men, older, younger, better-off and worse-off. However, equal and total inclusion is not easy to define , in addition, understanding how specific contexts affect different people's motivations to be involved in externally initiated participatory development processes has not been emphasised. Words such as participation and community often provide a smokescreen for professionals to circumvent intra-community challenges, particularly the micro-politics of gender relations (Guijt, 1999 \& Shah, 1998).

Despite the challenges associated with participatory development, appraisal of six projects sponsored by DFID (Kanji \& Salway, 2000), to examine the degree to which they tackle issues of gender equality, drew the following conclusion: Projects that adopt a participatory approach through deliberate consultation of females and males (in different stakeholder groups), at the initial stages as well as throughout the project life cycle are more likely to recognise genderspecific interests and to advance gender equality. However, this does not imply that participatory approaches will certainly support a discourse on unequal social relations nor always involve the less powerful groups, what it means is that, the approach gives room for more context-specific gender equality strategies than previous former top-down approaches.

One key challenge for gender-aware practice at community level is to extend the 'space' and time in which participation can take place, to everyday fora and not to consultations and one-off public events, where men may dominate. A consideration and appreciation of the practical conditions which facilitate the participation of women in specific cultures and contexts can make all the difference. Euler, (1995) in his studies in Bangladesh on the appropriate time for the participation of women established that 'Women prefer lunchtime'. This study is a clear example of how preference ranking with women and men in rural Bangladesh improved the opportunities for project supervisors to be able to meet with women. Nevertheless, women's disadvantaged economic status characterised by low income and heavy workload is a challenging issue in several parts of the world yet participation takes time. Sarin's (1998) example of community forest management is remarkably honest on how almost half of the women who were involved in making seasonal calendars of firewood and fodder availability had to leave before the end of the exercise so as to attend to multiple chores. Other studies have also come up with similar findings, for instance Agarwal (2001) in his study on community participation, noted that women rarely attend meetings. Mosse (1995) indicated that women's participation was minimal, very few attended development participatory processes, their attendance was discontinuous and they did not play a role in in the round up sessions.

The adoption of participatory time-use exercises can be a significant mechanism for sensitising men and mobilising for action, for instance, through investing in labour-saving devices. Bilgi (1998) explains the way in which male's understanding of female's work was enhanced through asking them to describe a women's day in villages in Gujarat, India. This exercise was conducted by the Aga Khan Rural Support Programme, as part of efforts to enable men develop a better understanding of women's strengths and capabilities to participate in community development. Similar exercises to map the daily activities of women and men have been used as part of gender training programmes, for example, with both villagers and project staff in East Africa in the mid-1990s (Kanji, 1995). Follow-up activities in zones where NGOs had been working indicated that some men had altered their behaviour over time. For instance, some were more willing to assist with the domestic chores while others feared that 'people would think they were over-powered by their wives' (SNV Tanzania, 1996).

The impact of liberalisation and privatisation has made it more problematic for women in various settings to participate in the public sphere. Research on the effects of liberalisation and privatisation, particularly structural adjustment policies, has revealed an increase in income and gender inequalities (Grown et al, 2005;Afshar, 2016 ).Groups who possess greater assets, both material and social, have been better able to exploit the neo-liberal, market-based development. The decrease in the responsibility of the state in making available the basic and social services has a negative effect particularly on women, who have gender-ascribed roles in caring for households. Similarly, more and more women have gained access into the paid labour market thereby increasing their workloads. A study on women's livelihoods conducted by the Aga Khan Foundation in Tajikistan demonstrated how women's increasing workloads, in the post-Soviet era, further constrained the chances of women to participate in the public sphere, even at the most basic level (Kanji, 2002). Mayoux (2014) emphasises that increasing workloads together with gender biases in the structures and processes of governance renders the rise in women's participation in public life more challenging. 


\subsection{Typologies of Participation}

Participation comes in a variety of forms (Zakus \& Lysack, 2011).The extent and kinds of participation are well differentiated by typologies. Some literature dwelt on the types of participation and how they are practiced while others focused on the approaches and mechanisms as well as their application in the process of participatory development. The strengths and weaknesses in applying them are also highlighted.

Arnstein's (1969) ladder of participation (Figure 2.1) is one of the best known and retains considerable contemporary relevance. Citizen control is the highest level of participation and therefore appears at the top of the ladder, on the other hand, non-participation is positioned at the bottom alongside therapy and manipulation. Arnstein's primary focus is the citizen who is on the receiving end of projects or programmes. She distinguishes between 'citizen power' and 'tokenism' ,for her, citizen power consist of citizen control, delegated power and partnership, while for the level of tokenism, she includes consultation, informing and placation.

\begin{tabular}{|c|}
\hline 8 Citizen Control \\
\hline 7 Delegated Citizen Power \\
\hline 6 Partnership \\
\hline 5 Placation \\
\hline 4 Consultation / Tokenism \\
\hline 3 Informing \\
\hline 2 Therapy \\
Non-participation \\
\hline 1 Manipulation \\
\hline
\end{tabular}

Table 1: Arnstein's Participation Ladder

Source: Arnstein, (1969), Cited in Boakye-Agyei, (2009)

Arnstein's (1969) typology for participation differentiates various levels of participation with respect to levels of or access to power and emphasises citizen control which is a key aim of participation. This typology sees citizen participation as power redistribution which provides opportunity for the poor and marginalized to be involved consciously in future decision making process (Boakye-Agyei, 2009). The ladder depicts participation as essentially a power struggle between citizens trying to move up the ladder, while controlling organisations and institutions, limiting their rise to the top by barring citizens abilities to claim control or power for themselves (ibid). According to Lennie and Tacchi (2013,) issues of power are an inevitable aspect of participatory approaches to development, communication for development andevaluation. Reducing power inequalitiesrequires specific attention to not only the knowledge, institutions, and best practice of professionals, but also the knowledge, institutions, and best practice of communities (Eversole, 2012: 31)

Carpentier, (2011) observes that participation can be in the form of lip service, a term aimed to mislead people with the promise of empowerment while reducing their agency at the same time. On the other hand, in the maximalist form, the consensus-oriented models of democracy (and participation) emphasize the importance of dialogue and deliberation and focus on collective decision-making based on rational arguments in a public sphere.Carpentier's distinction represent the ends of a continuum of participation that can be located on Arnstein's (1969) ladder of citizen participation. Non-participation can be equated to Carpentier's (2011) minimalist participation while 'Citizen power', the highest level of participation in Arnstein's ladder can be equated to Carpentier's(2011) maximalist participation.

Choguill, (1996) and some other writers have disagreed with Arnstein's participation ladder since citizens' access to control is not the only rationale for participation. In reviewing Arnstein's participation ladder in the context of development, Choguill, (1996) argued that individuals resort to self-management as the sole option when abandoned by the state due to lack of government support. To tackle the issues of community power in the political sphere and performance in urban services provision, Choguill developed a framework for community participation suitable for developing nations. This is shown in figure 2.2. She placed self-management at the bottom of the ladder instead of manipulation as represented by Arnstein.

\begin{tabular}{|c|}
\hline 1 Empowerment \\
\hline 2 Partnership Support \\
\hline 3 Conciliation \\
\hline 4 Dissimulation \\
\hline 5 Diplomacy Manipulation \\
\hline 6 Informing \\
\hline 7 Conspiracy Rejection \\
\hline 8 Self-Management Neglect \\
\hline
\end{tabular}

Table 2: A Ladder of Community Participation for Developing Countries

Source: Adapted From Choguill, (1996) 
Other dimensions raised by the International Association of Public Participation (IAP2) is whether having control should be the only aim of participation or successful participation can only occur relative to external power. They suggested a framework with a range of five goals to be the centre of participatory typology. Their framework (Table 1) indicates the goals for participation as informing, consulting, engaging, collaborating and empowering citizens. Their typology of participation shows the possible kinds of engagement with stakeholders and communities and depicting the rising degree of public impact as one moves from "inform" through to "empower". In spite of the dimensions highlighted by the framework, it does not give direction as to how the goals can be attained.

\begin{tabular}{|c|c|c|c|c|c|}
\hline & Inform & Consult & Engage & Collaborate & Empower \\
\hline Goal & $\begin{array}{c}\text { Provide the } \\
\text { public } \\
\text { with balanced } \\
\text { and } \\
\text { objective } \\
\text { information so } \\
\text { as } \\
\text { to assist them } \\
\text { understand the } \\
\text { problem, } \\
\text { alternatives, } \\
\text { opportunities, } \\
\text { and/ or } \\
\text { solutions }\end{array}$ & $\begin{array}{c}\text { Obtain } \\
\text { public } \\
\text { feedback on } \\
\text { analysis, } \\
\text { alternatives, } \\
\text { and/ or } \\
\text { decisions }\end{array}$ & $\begin{array}{l}\text { Work directly } \\
\text { with } \\
\text { the public } \\
\text { throughout the } \\
\text { process to } \\
\text { ensure } \\
\text { that public } \\
\text { concerns and } \\
\text { aspirations are } \\
\text { consistently } \\
\text { understood } \\
\text { and } \\
\text { considered }\end{array}$ & $\begin{array}{l}\text { Partner with } \\
\text { the } \\
\text { public in each } \\
\text { aspect } \\
\text { of the decision } \\
\text { including the } \\
\text { development of } \\
\text { alternatives } \\
\text { and the } \\
\text { identification } \\
\text { of the } \\
\text { preferred } \\
\text { solution }\end{array}$ & $\begin{array}{c}\text { Place final } \\
\text { decision making } \\
\text { authority in } \\
\text { the hands of } \\
\text { citizens }\end{array}$ \\
\hline
\end{tabular}

Table 3: IAP2 Participation Participatory Framework

Chin Saik Yoon also made a significant contribution to the literature on participatory communication for development by identifying four ways of observing participation in development projects, namely, participation in implementation, participation in evaluation, participation in benefit and participation in decision-making (Yoon, 2004).

According to Yoon (2004), in terms of participation in implementation people are actively encouraged and mobilized to take part in the actualization of projects whereby they are given certain responsibilities and set certain tasks or else they may be required to contribute specified resources. Upon completion of a project people are then invited to review either the success or the failure of the project - participation in evaluation. Yoon describes the third type of participation as participation in benefit which refers to the process of people enjoying the fruit of a project. Finally, he describes the last approach, participation in decision-making, in terms of which people initiate, discuss, conceptualize and plan the activities that they will conduct as a community.

While some development initiatives incorporate all four avenues of participation, there are development initiatives which are restricted to one or two. Nevertheless, Yoon (2004) claims that participation in decision-making is the most important form to utilize in the development process because it allows the members of a community power over their own lives and their environment. It is, therefore, of significance to acknowledge the fact that Yoon's theory emphasizes participation in decision-making, as this also empowers communities with the necessary skills and, more importantly, with the knowledge to take responsibility for changing their lives and, further, to sustain such change.

\section{Research Methodology}

\subsection{Research Design}

Exploratory research design was employed in this research. The study sought to generate a posteriori data that tested the relationships between the independent variables and the main dependent variable. The advantage of exploratory research is that it was easier to make new discoveries due to the less stringent methodological restrictions. The study focused on gender participation in communication for development, the research design gave more room for interpretation and understanding.

\subsection{Sample Size and Sample Selection}

The major aim of sampling in research is to identify the participants who are likely to give rich and in in depth information on the issue being studied so that we learn the most about it (Dörnyei, 2007).In this study, the researcher selected three categories of participants: county director of gender, ward administrators, leaders-chairpersons- of different women groups in Nyatike and Kuria East and members of the registered women groups. The county director of gender was chosen because she sets, co-ordinates and implements the gender agenda within the county. She is important for the study since the office is instrumental in formulating gender policies and planning projects for women and other marginalized groups. The ward administrators were chosen because of the role they play in identifying, communicating and coordinating county government projects within the wards. The researcher therefore considered the ward administrators key in communication for development. The women groups were chosen because development initiatives for females are channeled to the women through registered women groups. Leaders (chairpersons) and members of the women groups were preferred respondents because they were a good representation of the group members who in this 
case are females in Migori County.According to Rosengren, (1999) groups are characterised by structures that consist of leaders and members. So for this study, both group leaders and members of the groups were of interest for the researcher. The county director of gender and the leaders-chairpersons- of registered women groups were chosen through purposive sampling. Purposive sampling was used in this study because as Mugenda \& Mugenda (1999) assert, the focus is on indepth information on a particular issue and not on making inferences or generalizations. Hence, the study targeted participants who are known to have the information that served the purpose of this study, by virtue of their duties (Kombo \& Tromp, 2006). The members of women groups were chosen through snow ball sampling; the women leaders identified them .On the other hand, ward administrators were chosen through simple random sampling.

The study was conducted in two sub counties within Migori County: Nyatike and Kuria East. Migori County comprises of eight sub counties namely Rongo, Awendo, Uriri, Suna East, Suna West, Kuria East and Kuria West. Out of the eight sub counties, two sub counties were selected for the study because according to Mugenda (2008), 30\% sample size is sufficient to represent a population to be used in social science research. Based on this, $30 \%$ of the total sub counties in Migori County was used to determine the number of sub counties to be used in the study.30\% percent of the 8 sub counties in Migori County is 2 . These two sub counties were then chosen through purposive sampling due to their disadvantaged economic status. According to MICDP (2013) the highest number of those living below poverty line in Migori County are found in the marginal areas of Nyatike and Kuria East Sub-counties which experience unfavorable climatic conditions for agricultural production thereby making the inhabitants of the area susceptible to famine, drought and hunger.

Kuria East Sub County is made up of 5 wards while Nyatike is made up of 7 wards. Therefore the total number of ward administrators in the two sub-counties are 12 .The researcher employed Mugenda \& Mugenda 10 percent formula which resulted to a sample size of two ward administrators. The researcher then decided on the ward administrator for Kaler and Ntimaru East through simple random sampling.

The number of women groups for the research was arrived at through Mugenda and Mugenda's 10 percent formula. Out of the total 200 registered groups in Nyatike and Kuria East, the researcher settled on a sample size of 20 registered women groups. Thereby giving a sample size of 12 women groups in Nyatike and 8 women groups in Kuria East .However, to have equal proportion of groups in the two subcounties, the researcher decided to study 10 women groups in Nyatike and 10 women groups in Kuria East. The researcher then employed systematic sampling to arrive at the groups for the study. From the list of groups in the department of social work in Nyatike and Kuria East subcounties, every $5^{\text {th }}$ group on the list was chosen for the study. From the records in the social department women leaders-chairpersons -were purposively sampled for the study. Their telephone numbers which were later used for purposes of getting in touch with them for data collection were retrieved from the records in the department of social services. The other women-members of the groups were identified by the chairpersons.

The researcher selected the following categories of participants: county director of gender and equality, 2 ward administrators, 20 leaders of different women groups in Nyatike and Kuria East 20 other members of registered women groups. The sample size for the study was 43. According to various scholars, the question of sampling in qualitative research is rather sticky since there are no clear guidelines or standards on what may be considered the right number of samples. Most scholars agree that any sample of between 15 to 50 participants is adequate (Charmaz, 2006) suggests that 25 participants are adequate for smaller projects According to Ritchie et al (2003), qualitative samples often lie under 50 while Green \& Thorogood (2009) state that the experience of most qualitative researchers is that in the interview studies, little that is new comes out of transcripts after you have interviewed 20 or so people .For ethnography and grounded theory, ( Morse,1994) has suggested approximately 30 to 50 participants while (Cresswell, 2001) suggests between 20 and 30 participants for grounded theory and between 5 and 25 for phenomenological studies

\subsection{Methods of Data Collection}

During the study three main methods of data collection were employed. They include the use of interviews, focus group discussion and document analysis. The data collection methods were employed based on the indicators to be assessed and the objectives of study. The study relied on both primary and secondary sources of data. The following data collection methods were used:

\subsection{Interview}

Interview as a technique of generating data involve direct verbal interaction between individuals. It is intended to get what a participant in the research thinks, the attitudes of that person and/ or to explore a person's reasons for thinking in a certain way or for carrying particular perceptions or attitudes (Cohen, 2007). Furthermore, with the use of nonnumerical data, this line of research seeks to explore and describe the 'quality' and 'nature' of how people behave, experience and understand. Further to linking people's actions to their beliefs, Brown (2005) adds that one of the great strengths often cited for qualitative research is its potential for forming hypotheses. In a similar vein, Cohen et al (2007) add that interviewing is valuable method for exploring the construction and negotiation of meanings in a natural setting. Interviews made it easier to find crucial data that could answer research questions. Interviews also made it possible for the researcher to avoid mixing up the questions since she had the opportunity to explain the questions further so as to enable the respondents to provide relevant responses. The interviews enabled the researcher to develop a rapport with the participants and facilitate free exchange of information. According to Gillham (2005), the relationship between the interviewer and the interviewee is responsive or interactive, allowing for a degree of adjustment, clarification and exploration. 
Interviews suited this study in terms of the factors noted by Gillham (2005) who says that interviews are suitable when: small numbers are involved, they are accessible, they are key and you can't afford to lose any, your questions...are mainly open and require an extended response with prompts and probes...to clarify answers, if the material is sensitive in character so that trust is involved: people will disclose things in a face-to-face interview that they will not disclose in any anonymous questionnaire. The interviews were conducted at the participants' places of work, homes and forums for chama meetings. They were conducted in the language the participants are comfortable using, that is, English, Kiswahili, Luo and Kuria. The two Sub-counties: Nyatike and Kuria East where the study was conducted are predominantly inhabited by the Luos and the Kurias, therefore the local dialects were employed where the respondents neither spoke English or Kiswahili. In cases where Kuria language was the sole language employed, then the researcher sought translation services .Since these are the four languages the participants used, the researcher allowed for flexibility so that the information could be delivered appropriately. Interviews were more flexible for the participants were able to adapt to the situation and get as much information as possible. Very sensitive and personal information were extracted from the respondent by honest and personal interaction between the respondent and the interviewer. The interviewer clarified and elaborated the purpose of the research so that the respondents could give more complete and honest information. Interviewer was however, able to get such information through interaction and genuine conversation. Interviews yielded high response rates mainly because it was difficult for a subject to completely refuse to answer questions or ignore the interviewer (Gillham, 2005). The researcher interviewed the county director of gender, two ward administrators, a total of 15 leaders of women groups, 10 members of registered women groups found in Nyatike and Kuria East. The interviews were tape recorded so as to avoid any loss of information.

\subsection{Focus Group Discussion}

According to Sarantakos (2005), focus group is a loosely constructed discussion with a group of people brought together for purposes of a study.In focus group discussions (FGDS), a group of people are asked about their perceptions, beliefs and attitudes by the interviewer (Cresswell, 1994).The focus group discussions usually comprise of 6 to 12 members (Berger, 2009). The focus group discussions was guided by semi structured questions. Semi structured questions were preferred because they are more flexible and thus generate reliable data. The FGDs were considered important for this study because data is collected in a large group of environment, which provided a large volume of information from variety of perspective. FGDs provided an environment where participants express ideas without fear of criticism as well as create a fuller and deeper understanding of the phenomenon being studied. FGDs also stimulate spontaneous exchange of thoughts, ideas and attitudes in the security of being in a crowd (Des Vos et al.,2011).

According to Nielsen (1979), FGDs often bring out participants spontaneous reactions and ideas and let the researcher observe some group dynamics and organizational issues. This is because in many cases, the FGD is conducted as an open conversation in which each participant may comment on other participants' answers or respond to comments by others .To encourage wider participation and deal with dominant members , participants should be told that the presence of each of them and their perceptions are important for the discussion. At a practical level, FGDs are efficient in the sense that they generate large quantities of material from relatively short time. Equally, they foreground the importance not only of content, but also of expressions, because they capitalize on the richness and complexity of group dynamics (Kamberelis\&Dimitriadis, 2005).

One weakness of FGD is that it may be difficult to determine whether an individual's process is subject to group influence (Casey \& Krueger, 2000).Other problems may also arise from group management and logistics. However, these problems can be considered as part of the group dynamics which are useful for the study.

The researcher conducted one focus group discussions in Nyatike and anotherone in Kuria East. In Nyatike , the focus group consisted of 8 women ( 5 members of women group and 3 leaders) while in Kuria East the focus group consisted of 7 women ( 5 members of women groups and 2 leaders of women group).

\subsection{Document Analysis}

The use of document analysis as a data generation technique is also important to the researcher. Yin (2009) asserts that documentary information is likely to be very relevant to every case study topic. He further advises that this type of information can take many forms and should be the object of explicit data collection plans and that document are usually valuable in corroborating data from other sources. However, he cautions that it should not be assumed that all the information in documents is absolutely factual. Jwan \& Ong'ondo (2011) contend that documents are also important sources of data but cautions that using already printed documents is likely to be a tedious process. They further caution that there is a difference between using documents as a source of data and suggest that as far as possible a researcher ought to use only the raw documents as data since secondary documents could be used as background information or as part of the literature review. One advantage of document analysis as a source of data in qualitative research is that it enhances the credibility of the study, an important aspect of trustworthiness (Jwan \& Ong'ondo, 2011).The researcher had purposed to analyse the content of at least 10 sets of development communication messages in local radio stations in Migori County as well as 10 archived speeches of director of gender since 2013.However, the researcher only managed to receive 4 sets of communication for development messages from radio Milambo and 2 sets of speeches from the office of the county director of gender. Radio Milambo is the only station whose regional scope of operation is the whole of Migori County therefore that made it relevant for the study. In addition, the study analysed the Migori County Gender and Equality policy and the Migori CountyIntegrated Development Plan 2013-2017. The study had also intended to analyse the County Communication Policy, however, by the time the study was being conducted, the policy was not yet in existence. 


\subsection{Validity and Reliability of Instruments}

Anderson, (2010) notes that even though the terms reliability and validity traditionally have been associated with quantitative research, increasingly they are being seen as important concepts in qualitative research as well. Johnson\&Long, (2004) ; Noble \&Smith , (2014) assert that the tests and measures used to establish the validity and reliability of quantitative research cannot be applied to qualitative research, however, in the broadest context the terms ;validity and reliability are applicable to qualitative research.

\subsection{Validity of the Instruments}

In this study, validity of instruments was ensured by using simple language when constructing instruments for respondents to understand easily. Use of side notes to guide the respondents was also used to improve the validity of the instruments As another way of checking validity, the research instruments were given to two experts in the area for review to see whether they were answering the research objectives or questions that were to be investigated .The research supervisors also scrutinized the instrument and gave their inputs which were then integrated into the instruments to ensure face and content validity. During the data collection process, all the interview schedules were verified by the researcher to check whether all the questions were properly answered. This exercise ensured further validity of collected data.

\subsection{Reliability of Research Instruments}

Reliability can be defined as the extent to which a measurement instrument yields consistent, stable, and uniform results over repeated observation or measurements under the same conditions each time (Bowling, 1997). The purpose of reliability is to analyse the appropriateness of conceptual and operational definitions (Neuman, 2006; Wimmer \& Dominick, 2006). Consistency of the measurement is the concern of reliability (De Vos, 2001).Reliability is important for the success of any data collection procedure (Best \&Kahn, 2003).

The reliability of qualitative interview was through entering letters to verify the themes. The researcher used Cohen's Kappa Method to test reliability test of themes from inter-rater. The inter-rater reliability test is a way of judging through evaluating the agreement between two people or groups of observers or raters the level of a categorical variable. The measurement is needed in order to determine the suitability of coding and implementation of variables. The measurement ranged generally from 0 to 1.0, the higher level of reliability of data depends on high number of scores from the calculation.

Landis \&Koch (1977) outlined a more complete list of how Kappa might be interpreted.

\begin{tabular}{|c|c|}
\hline Kappa & Interpretation \\
\hline$<0$ & Poor agreement \\
\hline $0.0-0.20$ & Slight agreement \\
\hline $0.21-0.40$ & Fair agreement \\
\hline $0.41-0.60$ & Moderate agreement \\
\hline $0.61-0.80$ & Substantial agreement \\
\hline $0.81-1.00$ & Almost perfect agreement \\
\hline
\end{tabular}

Table 4: Interpreted List of Cohen Kappa

Source: Landis \& Koch (1977)

The researcher used kappa calculation to estimate the level of data reliability which is confidential interval minus expected number divide by 1 minus the expected number. She distributed six copies of inter-rater to two lecturers and two $\mathrm{PhD}$ students in order to get their observation about the themes. The results from the calculation of reliability test was 0.45 . The agreement between groups of observers shows that the level of agreement is moderate meaning that the themes were moderately accepted by observers.

\subsection{Data Collection Procedures}

The procedure for data collection started when the researcher was given a letter of approval by Rongo University to go to the field .Using the letter of approval, a permit to conduct the study was acquired from the the National Council of Science and Technology ( NACOSTI).The permit from NACOSTI was used to acquire a permit from the Migori County Commissioner and Migori County Education office.This was then followed by arrangement of meetings with key informants who included county director of gender and equality, ward administrators, women group leaders and members of women groups.The arrangements focused on the logistics of data collection and how to reach the target population. Interview schedules were set and target groups were mobilized and informed in advance on the logistics.

A cover letter stating the purpose, value of responding was attached guaranteeing participants confidentiality. The researcher would clear misconceptions and misunderstandings that may arise. Schedule of activities were drafted showing activities to review, success to uphold and failures to address on a daily work plan so as to tackle areas, which need improvement and help to avoid omission. Deliberations on viable approaches and challenging issues were included and used for effective planning. 


\subsection{Data Analysis Technique}

Data that was used in this study was in qualitative form. Views aired by Bryman \& Cramer (1999), are that analysis is to fulfill research objectives and provide answers to research questions. Thematic analysis was done to analyze qualitative data in the study through emphasizing indicatives, examinations and recording patterns within data (Braun \&Clark, 2006).The process involved transcribing and coding so as to create meaningful patterns. According to (Mugenda \& Mugenda, 2003), the process comprised of the following six steps: familiarization with the data, generation of initial codes, search for themes, review of themes, definition and naming of the themes and production of the report.

First and foremost, the data was transcribed and checked for accuracy with the help of content analysis. Content analysis is defined as a procedure for categorization of verbal or behavioural data for purposes of classification, examination of the intensity with which certain words, points of view and emotionally laden words are used to express experiences (Orodho,2010).The codes were then generated and data significant to each code collated. Emerging themes were noted from each code and collated into potential themes. The potential themes were then reviewed by checking against the coded extracts leading to a thematic map of analysis. The themes were then refined into specifics by generating clear definitions and names for each theme. Finally, vivid extracts from the transcriptions were selected, there were attempts to relate back the analysis to the research questions and literature in view of themes and objectives of the study (Braun \& Clark, 2006).

\begin{tabular}{|c|c|}
\hline Phase & Description of Process \\
\hline 1.Familiarization with the data & $\begin{array}{l}\text { Transcription of data through reading and re-reading the data while noting } \\
\text { down initial ideas. }\end{array}$ \\
\hline 2.Generalization of the initial codes & $\begin{array}{l}\text { Coding pertinent features of the data in a systematic manner across the } \\
\text { entire data set, as data relevant to each code is collated. }\end{array}$ \\
\hline 3.Search for themes & $\begin{array}{l}\text { Organising codes into prospective themes, collecting every data related to } \\
\text { individual would-be theme. }\end{array}$ \\
\hline 4.Review of themes & $\begin{array}{l}\text { Verifying whether themes are relevant to the coded extracts } \\
\text { creating a thematic plan of analysis. }\end{array}$ \\
\hline 5.Definition and naming of themes & $\begin{array}{l}\text { On-going analysis to refine the specific of each theme, and the overall story } \\
\text { the analysis tells, generating clear definitions and names for each theme }\end{array}$ \\
\hline 6.Production of the report & $\begin{array}{c}\text { The last step of data analysis. Choosing vivid excerpts, examples, final } \\
\text { analysis of the selected extracts, comparing the analysis to the research } \\
\text { question and literature, producing of a research report. }\end{array}$ \\
\hline
\end{tabular}

Table 5: Phases of thematic analysis

Source: Braun \& Clarke, 2006

While analyzing data, the researcher also drew from practices as outlined by Huberman \&Miles(2002).They summarize qualitative analysis in three steps: data reduction, data display, conclusion drawing and analysis. During data reduction, the researcher condenses volumes of data into quantifiable analytical units; data are manipulated and reconfigured in an attempt to discover patterns and connections not previously apparent. The researcher then summarizes complex data in charts, graphs and other illustrations requiring creative, interpretive skills to draw out the full meaning of relationships between units and to integrate these interpretations into meaningful account. In the same breadth, Anderson (2010) state that the researcher should select quotes that are poignant and/ or most representative of the research findings. Including large portions of an interview in a research paper is not necessary and often tedious for the reader.

\section{Findings of the Study}

\subsection{Participation of Females in Communication for Development by Migori County}

The study sought to establish the participation of the female gender in communication for development by Migori County .The following question was asked to the females: Do you participate in communication for development targeting females in Migori County? The responses from the respondents are given in italics. Apart from the ward adminstrators and the director of gender and equality, the respondent are referred to as " $\mathrm{R}$ ".They are also assigned a numerical value. 


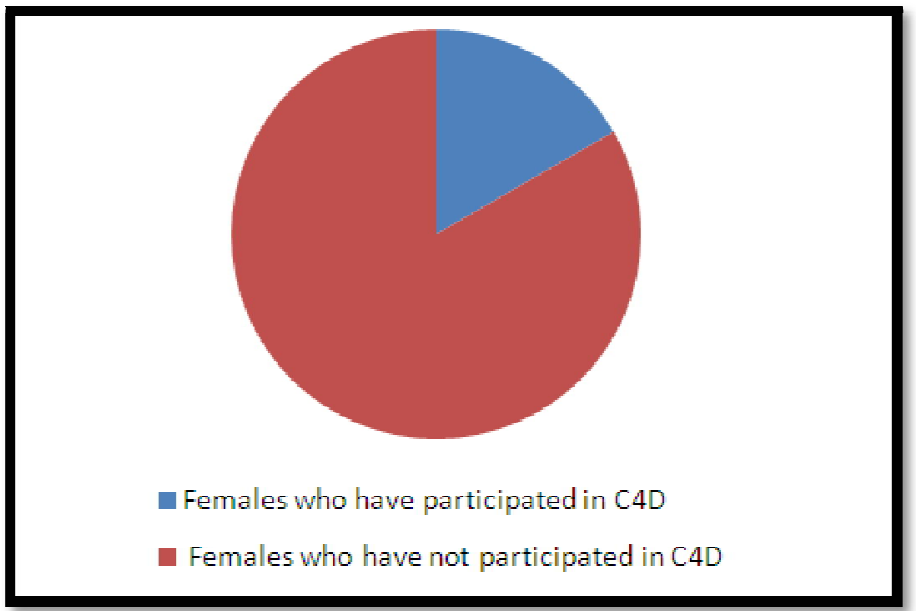

Figure 1: The Participation of Females in Communication for Development in Migori County

Females indicated that they hardly participated in communication for development .Only a small proportion indicated that they had participated in communication for development.

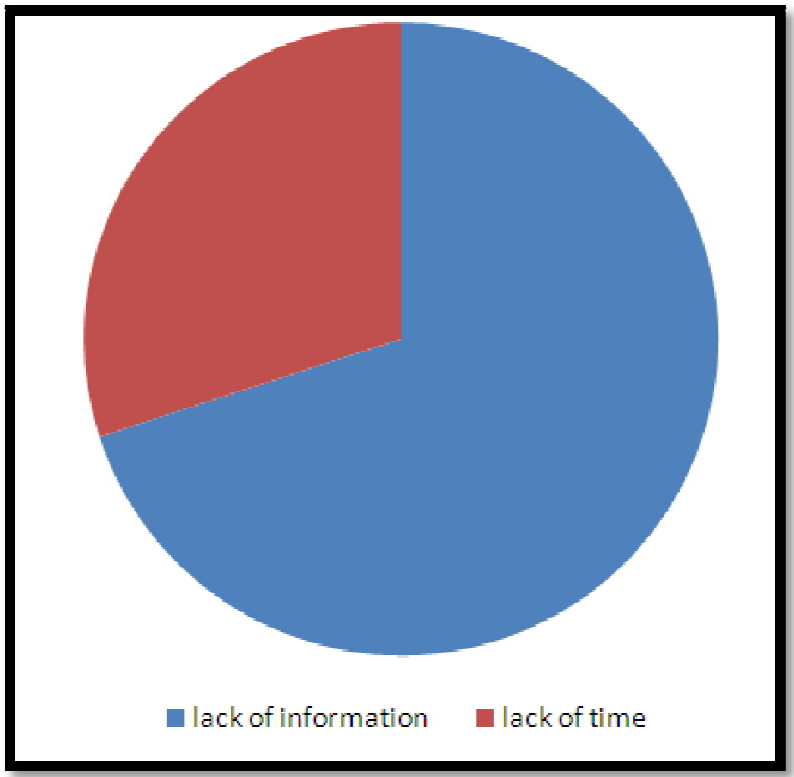

Figure 2: Reasons for Low Level of Participation in Communication for Development in Migori County

The females in Migori County indicated that they hardly participated in the communication for development majorly because they are never aware of the programmes. They lacked information on the opportunities for participation in the county. Lack of time also emerged as a reason for low participation in communication for development

\subsubsection{Interview Response}

R4 I have never heard of communication for development programmes.

R6 When are they ever held?

R10 Even, if I knew that there were meetings for development, I don't think I can find time to attend them .I have so much work to do ... I look after my children, clean the house, go to the shamba .....I must also look for money

From the focus group discussions, it emerged that as much as the females do not have time, communication for development programmes can be integrated into their already existing and socially accepted network such as church activities.

\subsubsection{Focus Group}

"Getting time to participate in communication for development by the county government is not easy, but we already belong to church groups whose meetings we hold regularly, the county government can use such forums for communication for development"

In church, women have grouped themselves into social, spiritual and even economic networks where they engage in financial savings and table banking. Such groups include the Catholic Women Association in the Catholic Church, the 
Women's Guild in the protestant church, the shepherdess and the Deaconess in the SDA church. These groupings in church attract large number of females. The females' level of commitment to these groups is also high; they dedicate a lot of their time to the meetings and activities of these groups. The county government of Migori should harness the capacity of these groups for communication for development.

The fact that the females are not aware of the opportunities for participation in communication for development points to the failure on the part of Migori county government to facilitate participation of females. As much as the constitution of Kenya ( 2010) and the County Government Act ( 2012) advocate for and provide a means for ensuring participation, the Migori County Integrated Development plan neither mentions nor provides strategies for facilitating participation.Migori County Gender Policy (2016) only defines the term participation but does not outline procedures of achieving it . Scholars have pointed out ineffective methods of participation and lack of participation as the reason for failure of project initiatives. According to Moser, (1995); Levy, (1996) while there have existed duplications in the procedures and approaches employed, gender activists have more often than not overlooked the significance of participation. In the same vein, more recently, there have been crucial deliberations on how to have a synergy of approaches so as to ameliorate both gender equality and participation in policy and planning processes, as well as in development programmes and projects (Guijt, 1998; Cornwall, 2000).

In view of the above findings, there is therefore a need for the county government to put in place measures that will ensure effective participation of females in communication for development in Migori County. Drawing from Giddens structuration theory, there is need for the county government to put in place structures that would enable effective participation of females. Such mechanisms include exclusive barazas-public meetings- for females. This will ensure success of communication for development and subsequently higher uptake of development initiatives and improved development status of females in Migori County.

The females in Migori County should also be encouraged to seek information on the gender issues in the county and to strive to be part of the gender sensitive development initiatives. Females should be sensitised on the importance of their participation in development programmes, they must be sensitised to create time to set the agenda of their development as well as take part in the development processes. The county government should regard participation as a right of females which must be granted. The females should also be sensitised on the importance of their participation in county governance and communication for development in particular. The females should be encouraged to claim their right to participation.

Out of the females interviewed for the study, only few indicated that they had benefitted from the county government development initiatives. Those females who had benefitted from the development initiatives by the county government indicated that they had often participated in communication for development targeting females in Migori County.

\subsubsection{Interview responses}

R1 When I get information of development meetings I sometimes go

R10 I have attended three of such meeting since 2013

\subsubsection{Focus Group}

"Few of us ... females... have participated in communication for development"

The females were also asked how they received information concerning the development initiatives in the county. The following question was therefore asked: How did you get to know of the development initiatives for females in Migori County? The females who have benefitted from the county government development initiatives indicated that they had received information from friends and relatives who work in the county government.

- R8 I got the information on development opportunities from my relatives who work in the county government

- $\quad$ R20 The information reached me through my relative in the county

- R11 A friend who works in the county government told me of the opportunities

Since only a few women claim to have participated minimally in communication for development in Migori County, this could point to the fact that the process may be dominated by a clique of women. Empirical research, reports that sometimes participation of females in development is inhibited by elite women and men. To illustrate this, a reference is made to the study of community forestry management in India by Sarin, (1998), in which he demonstrated how wealthy village men are apt to dictate the community priorities and decisions, while the women whose livelihoods are intertwined much more with the forests are compelled to abide by the men's rules. Despite the fact that Sarin's study focussed on participation of both females and males in community development while this study only focussed on participation of females, it still demonstrates how participation of females can be hijacked by others. In the case of Migori County, the elite women who monopolise participation in communication for development are those with higher social capital. Women whose relatives and friends are in position of power and authority in the county.

Lack of time for participation in communication for development was a recurrent reason for failure of women to participate in communication for development. Studies have been carried out to establish impediments to participation in communication for development. For instance Agarwal (2001) noted that women rarely attend meetings. Mosse (1995) indicated that women's participation was minimal, very few attended development participatory processes, their attendance was discontinuous and they did not play a role in the round up sessions. The reduction in the role of the state in providing basic and social services has particularly affected women, who have gender-ascribed roles in caring for households. At the same time, there has been a rapid and substantial increase in the proportions of women in paid work 
over the last two decades. What this means is that women tend to face increasing workloads. A study of women's living conditions conducted for Aga Khan Foundation in Tajikistan, revealed ways in which women's rising workloads, in the post-Soviet era, have rendered more difficult the participation of women in the public sphere and even at the local level (Kanji, 2002). Increasing workloads combined with gender biases in the structures and processes of governance make it more difficult to increase women's participation in public life. There is therefore a need for redistribution of labour at the domestic level, to enable the females to have time to participate in communication for development. Household duties should be shared equally between females and males to enable females get time to participate in communication for development and in the public affairs.

\subsection{The Form of Participation of Females in Communication for Development by Migori County Government}

The study also aimed to establish the nature of participation in communication for development. Therefore this question was posed to the females: What is the nature of your participation in communication for development in Migori County? The females indicated that the nature of participation was information sharing.

\subsubsection{Interview Responses}

- R9 Usually, the county government official informs us of the development opportunity available and how to benefit from the opportunity

- R13 We are told how to apply for the development opportunities

\subsubsection{Focus Group}

The county government tell us about the development opportunities, we listen, they talk

The county government officials represented by county director of gender, ward administrators indicated that the level of participation in communication for development has been information sharing.

\subsubsection{Ward Administrator 1}

At Baraza, general public meetings we inform the public of development opportunities

Information sharing is a limiting form of participation. Arnstein (1969), Choguil, (1996)\& IAP (2000) are in agreement that information sharing is one of the lowest forms of participation. The county government of Migori should put in place forms of participation that are more empowering to the females such as partnership and empowerment.Yoon's ( 2004) emphasizes participation in decision-making, as this also empowers communities with the necessary skills and, more importantly, with the knowledge to take responsibility for changing their lives and, further, to sustain such change.

\subsection{The Nature of Communication in the Process of Participation In Communication for Development}

The study also sought to establish the nature of communication in the process of participation. To that end, this question was asked: What is the nature of communication for development targeting females? The females indicated that the nature of communication for development was largely monologic.

\subsubsection{Interview Responses}

- R3: In the meetings for development, the county government official tells us of the development opportunities and how we can benefit from them.

- $\quad$ R13The county officials talk to us ... we hear them

- R10 The county officials speak to us about how we can get grants, seedlings from the county

\subsubsection{Focus Group}

\subsubsection{The Communication Is One Way: We Listen to the County Officials}

For communication for development to be effective, it should be dialogic. The monologic nature of communication for development renders the process ineffective thereby failing to facilitate development. Freire's theory focuses on the premise that, in order for communication to be effective, it is essential that it be participatory, dialogic and reciprocal (Freire, 1970). According to GCIS ( 2009) \& Baofo, (2006 ), communication for social change involves people taking the communication processes that will allow them to make their voices heard into their own hands to establish horizontal dialogue with planners and development specialists, and to make decisions on those development issues that affect their lives in order, ultimately, to achieve social changes for the benefit of their community .In regards to this, the county government should practice dialogic form of communication for development. Dialogic communication can be achieved through community media.

\section{Recommendations}

The county government of Migori should give priority to the participation of the female gender in the communication for development targeting females .The county government should regard participation as a right of females. The county government should therefore put mechanisms that will ensure that the female gender participate in the communication for development targeting them. One such mechanism is the use of community radio and exclusive barazas-public meetings for females. This will ensure the success of the communication for development programmes and subsequently improved development of females in Migori County. The county government of Migori should strive to 
employ more empowering forms of participation such as conciliation and empowerment in order to strengthen the capacities of females. Further, there is need to review Migori County Integrated Development Plan (MICDP 2013-2014) and the Migori County gender policy (2016) to detail thepractice participation.In addition, the female gender should also be encouraged to seek information on the gender issues in the county and to strive to be part of the gender sensitive development initiatives. Women should be sensitised on the importance of their participation in development programmes, they must be sensitised to create time to set the agenda of their development as well as take part in the development processes. On the same note, household duties should be shared equally between females and males to enable females get time to participate in communication for development and in the public affairs.

\section{Conclusion}

The study established that females in Migori County rarely participate in communication for development programmes in the county because they hardly receive information on opportunities to participate in communication for development. The females also indicated that the nature of participation in communication for developmentwas information sharing. The study recommends that the county should strengthen participation of females in communication for development through establishing community radio and encouraging exclusive female barazas- public meetings. In addition, the county government should employ more empowering forms of participation such as conciliation and empowerment. The study recommends a similar study be conducted to establish the level of participation of other constituents such as the youth among others in the communication for development process. In addition studies should be conducted to investigate the reluctance of women in participation in the communication for development process.

\section{References}

i. Amadiume, I. (2015). Male daughters, female husbands: Gender and sex in an African society. Zed Books Ltd.

ii. Anderson, C. (2010). Presenting and evaluating qualitative research. American journal of pharmaceutical education, 74(8), 141.

iii. Arnstein, S. R. (1969). A ladder of citizen participation. Journal of the American Institute of planners, 35(4), 216-224.

iv. Boafo, K. S. T. (2006). Participatory development communication: an African perspective. People, land \& water. Participatory Development Communication for Natural Resources Management.

v. Bessette, G. (2005).12-Participatory Development Communication: Reinforcing the Participatory NRM Research and Action Process.

vi. Bourgignon, F. (2015). Equity and economic growth: Permanent questions and changing answers? Background paper prepared for the 2016 Human Development Report, UNDP, New York.

vii. Bryman, A., \& Cramer, D. (1999). Quantitative data analysis with SPSS release 8 for Windows. A guide for social scientists. London and New York: Taylor \& Francis Group.

viii. Carpentier, N. (2011). Media and participation: A site of ideological-democratic struggle. Bristol: Intellect.

ix. Casey, M. A.\& Krueger, R. A. (2014). Focus groups: A practical guide for applied research. Sage publications.

x. Charmaz, K. (2006). Constructing grounded theory: A practical guide through qualitative research. Sage Publications Ltd, London.

xi. Clarity, R.G. (2013). Devolution inKenya.https:/ / www.wsp.org/ sites/ wsp.org/ publications/ devolution-in-Kenya.pdf.

xii. Creswell, J. W. (1994). Research design: Qualitative \& quantitative approaches. Sage Publications, Inc.

xiii. Creswell, J. W., \& Inquiry, Q. (2007). Research design: choosing among five approaches.

xiv. Cornwall, A. (2000) Making a Difference? Gender and Participatory Development. IDS Discussion Paper, no. 378. November

xv. De Vos, A. S., Delport, C. S. L., Fouché, C. B., \& Strydom, H. (2011). Research at grass roots: A primer for the social science and human professions.

xvi. Dornyei, Z. (2007). Research methods in applied linguistics.

xvii. Chin, S. Y. (1993). Asian development communications in the 1990s. Cultural expression in the global village, 115140.

xviii. Cohen, S. I. (1996). Mobilizing communities for participation and empowerment. Participatory communication for social change, 24, 223

xix. Economic Survey (2017). Ministry of Devolution and Planning.www.devolutionplanning.go.ke.

xx. Eversole, R. (2012). 'Remaking participation: Challenges for community development practice', Community Development Journal, Vol. 47 No. 1, pp. 29-41.

xxi. Freire, P. (1970). Pedagogy of the Oppressed, trans. Myra Bergman Ramos. New York: Continuum, 65-80.

xxii. Gilham, B. (2005). Research interviewing: the range of techniques. Continuum, London.

xxiii. Guijt, I. and Shah M.K. (1998) (eds) The Myth of Community, Gender Issues in Participatory Development, London: IT Publications.

xxiv. Green, J., \& Thorogood, N. (2009). Principles and approaches in qualitative research

xxv. Howley, K. (ed.). (2010). Understanding community media. Thousand Oaks: Sage.

xxvi. Kamberelis, G., \& Dimitriadis, G. (2005). Focus groups: strategic articulations of pedagogy, politics, and research practice. Handbook of qualitative research, 875-895.

xxvii. Lennie, J., \& Tacchi,J. (2013). Evaluating communication for development: A framework for social change. Routledge. xxviii. Lorber, J. (2004). "Night to his day": The social construction of gender. Race, class, and gender in the United States: An integrated study, 6, pp. 54-65. 
xxix. Manyozo, L. (2006). Manifesto for Development Communication: Nora Quebral and the Los Baños School of Development Communication editor's note. Asian Journal of Communication. 16: 79-99.

xxx. Mongella, G. (1995). Moving beyond rhetoric in women : Looking beyond 2000.New York .United Nations Publications

xxxi. Moser, C. (2015). Gender planning and development: Theory, practice and training. Routledge.

xxxii. Mugenda and Mugenda (1999). Research Methods .Quantitative and Qualitative approaches, Nairobi:ACTS Press.

xxxiii. Mugenda and Mugenda. (2008). Social Science Research : Conception, Methodology and Analysis,Nairobi:ACTS Press

xxxiv. Ngomba, T. (2016). What is "development" for? Communication sources Development. 3: 29-32.

xxxv. Orodho, A. J. (2010). Essentials of educational and social science research methods. Nairobi: Masola Publishers.

xxxvi. Parpart, J.L., Rai, S.M. and Staudt, K.A. eds. (2013). Rethinking empowerment: Gender and development in a global/ local world. Routledge.

xxxvii. Quebral, N.C. (2006). Development communication in a borderless world. Global Times. 3: 33-43.

xxxviii. Rees, D., Momanyi, M., Wekundah, J., Oyure, A.O., Andima, D., Musembi, F. and Mwaura, L. (2016). Agricultural knowledge and information systems in Kenya: implications for technology dissemination and development. Overseas development institute (ODI). Agricultural research and extension network (AgREN).

xxxix. Rogers, E.M. (2016). Communication and development: The passing of the dominant paradigm. Communication Research. 3: 213-240.

xl. Sarin, S. C. (1998). A survey of the assembly line balancing procedures. Production Planning \& Control, 9(5), 414434.

xli. Sen, A. (1999). Freedom as development.Delhi: BRPC.

xlii. Servaes, J. ed. (2008). Communication for development and social change. SAGE Publications India.

xliii. Schegg, R. and Stangl, B. (2017). Information and communication technologies in Tourism 2017. Springer.

xliv. Servaes, J. (2008). Communication for development approaches of some governmental and non-governmental agencies. Communication for development and social change, 201.

xlv. Sterling, S. R., O'brien, J., \& Bennett, J. K. (2007, December). Advancement through interactive radio. In 2007 International Conference on Information and Communication Technologies and Development (pp. 1-8). IEEE.

xlvi. Stern, S.J. (1997). The secret history of gender: Women, men, and power in late colonial Mexico.University of North Carolina Press.

xlvii. Treichler, P.A. and Wartella, E. (2006). Interventions: Feminist Theory and Communication Studies .Communication. 9:1-18.

xlviii. Tri, H.C.(1986a). General introduction. (In Jn, H.C. ed. Participate in development. India: Thomson Press, p. 9-32.)

xlix. Tri, H.C.(1986b). Popular participation in development: the problems, the conditions for its implementation and the fields of competence of Unesco. (In Tri, H.C. ed. Participate in development. India: Thomson Press, p. 35-57.)

1. Thomas, A. (2017). Development. In Gregory, D. Dictionary of Human Geography, 5th edition (pp. 155-56). WileyBlackwell.

li. Thomas, P.N. (1994). Participatory development communication: philosophical premises. (In White, S.A., Nair, K.S. \& Ascroft, J. eds. Participatory communication: working for change and development. New Delhi: Sage. p. 49-59.)

lii. Vainio-Mattila, A. (1999) Navigating Gender: a framework and a tool for participatory development. Manual for applying the often theoretical understanding of gender issues into practical development work. FinnishMinistry of Foreign Affairs, Department for International Development Corporation/ FINNIDA. Available at www.eldis.org/gender/index.htm

liii. Winship, J. (2013). Inside Women's Magazines. London: Pandora Press.

liv. White, S.A., Nair, K.S. \& Ascroft, J. eds. Participatory communication: working for change and development. New Delhi: Sage. p. 95-116.)

lv. Yoon, C.S. (2004). Participatory communication for development. http:// www.southbound.com.my/ communication/ parcom.htm Date of access: 25 Aug. 2008

Ivi. Zakus , M. R., \& Lysack, C. L. (2011). Refashioning one's place in time: Stories of household downsizing in later life. Journal of Aging Studies, 25(3), 243-252. 